\title{
Insect-resistant Bt-maize response to the short-term non-target mite-pest infestation and soil drought
}

\author{
Michał Świątek • Małgorzata Kiełkiewicz • \\ Barbara Zagdańska
}

Received: 7 March 2014/Revised: 16 June 2014 / Accepted: 17 July 2014/Published online: 29 July 2014

(C) The Author(s) 2014. This article is published with open access at Springerlink.com

\begin{abstract}
Transgenic lepidopteran insect-resistant maize expressing the crylAb gene $(\mathrm{Bt})$ and its non-transgenic counterpart at the 12-leaf-stage $\left(\mathrm{V}_{12}\right)$ were infested by the two-spotted spider mite or dehydrated by cessation of soil watering to check Bt-maize capacity to respond to other stresses than those assured by the presence of Cry protein. Since the antioxidant enzymes are key components of plant defence against biotic and abiotic stresses, the engagement of leaf superoxide dismutase (SOD), catalase (CAT) and peroxidase (POX) in response to 6-day mite feeding and soil drought has been investigated. The reduction of leaf hydration and soluble protein content in the fully expanded 8th leaf was independent of genotype and more pronounced in response to water cessation than mite infestation. Similarly, the changes in enzyme activities depended more on the kind of stress than the presence of the
\end{abstract}

Communicated by E. Kuzniak-Gebarowska.

Electronic supplementary material The online version of this article (doi:10.1007/s11738-014-1641-6) contains supplementary material, which is available to authorized users.

\footnotetext{
M. Świątek · M. Kiełkiewicz ( $₫)$

Department of Applied Entomology, Faculty of Horticulture, Biotechnology and Landscape Architecture, Warsaw University of Life Sciences-SGGW, Nowoursynowska 159, 02-776 Warsaw, Poland

e-mail: malgorzata_kielkiewicz@sggw.pl

Present Address:

M. Świątek

Institute of Microbial Technologies, Solidarnosci Avenue 17, 62-700 Turek, Poland

B. Zagdańska

Department of Biochemistry, Faculty of Agriculture and

Biology, Warsaw University of Life Sciences-SGGW,

Nowoursynowska 159, 02-776 Warsaw, Poland
}

transgene. Water shortage in the soil enhanced the activity of all enzymes, whereas mite feeding decreased the activity of SOD and CAT, and markedly increased POX in the 8th leaf of both cultivars. In mite-infested leaves of the nontransgenic plant, the CAT activity remained unaffected, whereas decreased in leaves of Bt maize due to the hampered activity of CAT-2. In comparison to the control, all enzyme activity in the 10th non-infested leaf of miteinfested non-transgenic maize decreased, whereas it changed in the 10th leaf of $\mathrm{Bt}$ maize in the same way as in the 8th mite-infested leaf. The results suggest that SOD, CAT and POX can strongly confer short-term drought-stress response in both maize cultivars, whereas POX is the only responsive enzyme in mite-infested $\mathrm{Bt}$ maize.

Keywords Bt-transgenic crop - Biotic/abiotic stresses · Tetranychus urticae $\cdot$ Water shortage $\cdot$ Superoxide dismutase $\cdot$ Catalase $\cdot$ Peroxidase

\section{Introduction}

Maize is one of the highest value crops, which is cultivated for its seeds, fodder and fresh consumption. During cultivation, maize plants suffer from several environmental stresses amongst which soil water deficiency and a broad spectrum of arthropod pests are the most severe (Ahmed and Mekki 2005; Meissle et al. 2010). Until now only transgenic insecticidal- and/or herbicide-resistant plants have been commercially available. The transgenic maize expressing the gene from the bacterium Bacillus thuringiensis var. kurstaki $(\mathrm{Bt})$ codes for the insecticidal Cry protein that is toxic to the European Corn Borer, ECB (Ostrinia nubilalis (Hübner), Insecta: Lepidoptera: Pyralidae), the serious agronomic pest of maize crop. 
Biochemical, proteome and/or transcriptome analyses have provided evidence that reactive oxygen species (ROS)-scavenging enzymes are an important component of the plant defence response against leaf chewing, and cell content- and phloem/xylem-feeding insects (Huang et al. 2007; Smith and Boyko 2007; Kuśnierczyk et al. 2008; Rani and Jyothsna 2010; Zhou et al. 2010; He et al. 2011). However, the engagement of antioxidant enzymes in defensive processes in host plants upon attack by insect herbivores depends on the plant species, its developmental stage, pest feeding behaviour (chewing vs. piercing-sucking) and the duration of infestation.

The two-spotted spider mite, TSSM (Tetranychus urticae Koch, 1836, Acari: Prostigmata: Tetranychidae), is a generalist which infests both dicots and monocots including maize plants. TSSM feeding results in cellular disorganization (Kielkiewicz 1999) leading to the lesion formation at the site of feeding and strong desiccation of leaves (De Angelis et al. 1983). The engagement of ROSscavenging enzymes in the defensive process in the host plant infested by mite herbivores mostly concerns dicots (Hildebrand et al. 1986; Bronner et al. 1991; Stout et al. 1994; Tomczyk 2001; Kielkiewicz 2002; Kielkiewicz et al. 2008; Masserti et al. 2011).

Low molecular weight antioxidants (ascorbic acid, glutathione and tocopherols) and ROS-scavenging enzymes [superoxide dismutase (SOD), catalase (CAT), ascorbate peroxidase, glutathione peroxidase, other peroxidases and enzymes of the ascorbate-glutathione cycle] are the most commonly activated to protect stressed plant tissue against damage caused by the overproduction of potentially harmful ROS (Foyer and Noctor 2011). Generally, it seems that the higher the capacity to balance ROS, the higher the tolerance to stress (Zhang et al. 2007; Gill and Tuteja 2010; Miller et al. 2010; Foyer and Noctor 2011; Singh et al. 2012). However, stress-induced responses are rather specific processes than the general consequences of stressinduced formation of reactive oxygen and/or nitrogen species (Neill et al. 2002; Jaspers and Kangasjärvi 2010; Torres 2010). The specificity of plant responses to both, abiotic and biotic stresses, may be a result of a different chemical identity of these species, their different sub-cellular localization and interactions with jasmonic acid, salicylic acids, ethylene, auxin and abscisic acid (Kwak et al. 2006; Ślesak et al. 2007; Miller et al. 2010; Bartoli et al. 2013). Even if the same transcripts are induced by different stresses (pathogen attack vs. drought) they can be displayed at different periods of time, at different intensity or in various organs (Fossdal et al. 2007).

Development of new cultivars of agronomically important plants conferring resistance to particular or different stresses is a major challenge of conventional or transgenic plant breeding. However, programmes focusing on resistance to a particular stress often do not test resistance/susceptibility to other stresses either biotic or abiotic and this may have unpredictable consequences (Atkinson and Urwin 2012) as in the case of transgenic Bt cotton expressing insecticidal Cry protein (Chen et al. 2005; Dong and $\mathrm{Li}$ 2007). To address this issue, in the present study our attention has been focused on the engagement of key antioxidant enzymes (SOD, CAT, POX) in Bt maize response to short-term attack of a non-target mite pest or episodic soil drought, two stresses to which plants are often exposed under field conditions. To compare antioxidant responses of non-transgenic and transgenic maize at the same developmental stage as environmental stresses often appearing under field conditions, the assessment of $\mathrm{Bt}$ maize and its non-Bt counterpart at the 12-leaf-stage $\left(\mathrm{V}_{12}\right)$ has been carried out.

\section{Materials and methods}

Plant material and experimental design

Experiments were carried out on maize (Zea mays L.) transgenic cultivar MON 810 (DKC 3421, YG, Monsanto Europe S.A., hereinafter referred to as $\mathrm{YG}$ ) expressing the $c r y l A b$ gene from the bacterium $B$. thuringiensis var. kurstaki $(\mathrm{Bt})$ responsible for plant resistance to ECB and the non-transgenic cultivar (DKC 3420, Monsanto Europe S.A., hereinafter referred to as ISO) which does not confer resistance to ECB.

Plants were grown in individual pots filled with peat substrate in a greenhouse under natural conditions of irradiation and photoperiod. Eight-week-old plants at the 12-leaf-stage $\left(\mathrm{V}_{12}\right)$ of both cultivars were divided into three experimental groups. Each group consisted of (1) control plants, watered twice a day, (2) plants subjected to TSSM feeding (40 females per leaf from the 7 th to 9 th, counting from the bottom) for 6 days and (3) plants subjected to soil drought evoked by cessation of watering for 6 days. Six plants were used per treatment.

Females of TSSM, from the synchronized lab colony reared continuously on bean plants under long-day conditions (16/8-h photoperiod; $24 / 18{ }^{\circ} \mathrm{C}$ day/night temp.), were transferred to the non-infested bean leaves (40 females per leaf). Leaves were separated in Petri dishes and kept in a refrigerator for $24 \mathrm{~h}$ to starve females. Then, bean leaves were fixed to the middle part of fully expanded 7 th, 8 th and 9 th maize leaves to let females move from the drying bean leaf to the given maize leaf. The majority of inspected leaves were inhabited by the number of females that was treated as initial (e.g. 40 per leaf) and all of them were found to be continuously feeding. In some cases when females were missing, individuals were added to the leaf to 
maintain the initial number. The 10th leaf was left 'free of mite'.

After 6 days, mite-infested leaves (from 7th to 9th) and non-infested (the 10th leaf) were detached from the control, mite-infested and drought-treated plants. Whilst taking samples from the 10th leaf (mite-free), they were once more inspected to be sure that they were without TSSM presence or damage. Leaf samples were frozen and stored at $-80{ }^{\circ} \mathrm{C}$ until use.

\section{Evaluation of leaf water content}

Discs (20 $\mathrm{mm}$ in diameter) were cut from the middle part of freshly harvested leaves (from 7th to 10th), weighed immediately (fresh weight, FW) and reweighted after $24 \mathrm{~h}$ water saturation in the dark (saturated weight, SW). Oven dried $\left(105^{\circ} \mathrm{C}\right)$ leaf discs were weighed (dry weight, DW) once again. Relative water content (RWC) was expressed as $(\mathrm{FW}-\mathrm{DW}) /(\mathrm{SW}-\mathrm{DW}) \times 100 \%$ as described by Barrs (1968). Two series of independent experiments were carried out and three independent batches of leaf material $(n=6)$ were collected.

\section{Protein extraction and determination}

Leaf tissues ( $1 \mathrm{~g}$ ) were ground in liquid nitrogen and extracted in $5 \mathrm{ml}$ of pre-cooled extraction buffer $(50 \mathrm{mM}$ Tris-HCL pH 7.5 supplemented with $8.9 \mu$ l 2-mercaptoethanol) containing $1 \%(\mathrm{w} / \mathrm{v})$ insoluble polyvinylpyrrolidone (PVP). The homogenate was centrifuged at $20,000 \mathrm{~g}$ for $20 \mathrm{~min}$ at $4{ }^{\circ} \mathrm{C}$ and supernatant was directly used for the enzyme assays. The soluble protein content in leaf extracts $(n=6)$ was determined according to Bradford (1976) using bovine serum albumin (BSA) as a standard.

\section{Antioxidant enzyme activity}

\section{Spectrophotometric assays}

The SOD (EC 1.15.1.1) activity in maize leaf extracts was assayed in the reaction mixture containing $2 \mu \mathrm{M}$ riboflavin, $13 \mu \mathrm{M}$ methionine, $75 \mu \mathrm{M}$ nitroblue tetrazolium (NBT) in $0.1 \mathrm{M}$ phosphate buffer $\mathrm{pH} 7.8$ and $100 \mu \mathrm{l}$ of enzyme extract in a final volume of $700 \mu \mathrm{l}$. After $20 \mathrm{~min}$ of incubation in room temperature, the absorbance of samples was recorded at $560 \mathrm{~nm}$ (Fridovich 1986). One unit of SOD was defined as the enzyme activity inhibited by $50 \%$ the photoreduction of nitroblue tetrazolium to blue formazan.

The CAT (EC 1.11.1.6) activity was assayed by monitoring the decomposition of hydrogen peroxide at $240 \mathrm{~nm}$ for $30 \mathrm{~min}$ (Rao et al. 1996). The reaction mixture contained $100 \mathrm{mM}$ potassium phosphate buffer $\mathrm{pH}$ 7.0, $0.5 \mathrm{mM}$ EDTA, $16 \mathrm{mM} \mathrm{H}_{2} \mathrm{O}_{2}$ and $100 \mu \mathrm{l}$ enzyme extract in $2.9 \mathrm{ml}$ total volume. One unit of catalase activity was defined as the $\mu$ mol hydrogen peroxide removal per min.

The POX (EC 1.11.1.7) activity was determined in the reaction medium consisting of $0.99 \mathrm{ml} 50 \mathrm{mM}$ acetate buffer $\mathrm{pH} 5.6,0.5 \mathrm{ml} 20 \mathrm{mM}$ guaiacol and $0.5 \mathrm{ml} 60 \mathrm{mM}$ $\mathrm{H}_{2} \mathrm{O}_{2}$. The reaction was initiated by the addition of $10 \mu \mathrm{l}$ of enzyme extract (Patykowski et al. 1988) and the increase in absorbance at $485 \mathrm{~nm}$ was monitored during $4 \mathrm{~min}$. For these assays, 1 unit of POX activity was defined as $1 \mu \mathrm{mol}$ of guaiacol oxidized in $1 \mathrm{~min}$.

The specific activities of all enzymes were expressed as units per gram of DW and per $\mathrm{mg}$ of protein as well.

\section{In-gel detection}

For separation of proteins by native polyacrylamide gel electrophoresis (PAGE), leaf protein extracts were concentrated using a vacuum centrifuge (JW Electronic) and separated in $11 \%$ native polyacrylamide gels containing $10 \%$ glycerol (Laemmli 1970) using a Mini-Protean II electrophoresis unit (Bio-Rad). The electrodic buffer consisted of $25 \mathrm{mM}$ Tris-glycine $\mathrm{pH}$ 8.3. Samples equal to the $40 \mu \mathrm{g}$ protein were mixed with $10 \%$ sucrose and $0.007 \%$ bromophenol blue prior to loading and run at a constant current of $30 \mathrm{~mA}$.

To reveal the SOD activity bands, gels were incubated $20 \mathrm{~min}$ in the dark in $50 \mathrm{mM}$ sodium phosphate buffer, $\mathrm{pH}$ 7.8 containing $0.24 \mathrm{mM} \mathrm{NBT}$ and $28 \mu \mathrm{M}$ riboflavin and then, immersed in $50 \mathrm{mM}$ sodium phosphate buffer, $\mathrm{pH} 7.8$ containing $28 \mathrm{mM}$ tetramethylethylenediamine (TEMED) and exposed to a light source at room temperature (Beauchamp and Fridovich 1971). Identification of different SOD bands was based on their sensitivity to $3 \mathrm{mM} \mathrm{KCN}$ and $5 \mathrm{mM} \mathrm{H}_{2} \mathrm{O}_{2}$ added during activity staining (Fridovich 1986) to distinguish amongst $\mathrm{Cu} / \mathrm{Zn}$-SODs (inhibited by both $\mathrm{KCN}$ and $\mathrm{H}_{2} \mathrm{O}_{2}$ ), Fe-SOD (inactivated by $\mathrm{H}_{2} \mathrm{O}_{2}$ ) and Mn-SODs (resistant to both inhibitors).

The CAT (EC 1.11.1.6) activity bands in gels were detected after native PAGE in $7.5 \%$ polyacrylamide. Gels were incubated in $0.003 \% \mathrm{H}_{2} \mathrm{O}_{2}$ for $10 \mathrm{~min}$ and stained in $1 \%$ ferric chloride and $1 \%$ potassium ferricyanide solution (Salin and Lyon 1982).

The POX activity bands were stained after native PAGE in $11 \%$ polyacrylamide. Gels were incubated in $50 \mathrm{mM}$ sodium acetate buffer, pH 5.0 containing $2 \mathrm{mM}$ benzidine (dissolved in dimethyl sulfoxide, DMSO). The reaction was initiated by $3 \mathrm{mM} \mathrm{H}_{2} \mathrm{O}_{2}$ and continued until the appearance of bands (Rao et al. 1996).

Statistical analysis

All the results are given as the mean of three individual leaves detached from three separate plants with two 
replicates in each. The non-parametric H Kruskal-Wallis test was used for data concerning leaf RWC and protein content. Arcsine transformation of percentages was performed before non-parametric analysis. Two-way ANOVA and HSD Tukey test $(\alpha=0.05)$ were performed to determine the significance of differences between transformed (Box-Cox) means of SOD, CAT and POX (Statistica 10.0 software).

\section{Results}

TSSM infestation of successive maize leaves (7th, 8th and 9th) resulted in similar changes in leaf water and soluble protein contents, in the activities of antioxidant enzymes and their electrophoretic patterns. Therefore, the results for only the 8th (mite infested) and 10th (non-infested, close to the mite infested) leaves are presented.

Table 1 The water content (expressed as RWC, \%) in the 8th and 10th leaf of maize plants subjected to soil drought (both leaves) or TSSM feeding (8th leaf)

\begin{tabular}{|c|c|c|c|c|}
\hline \multirow{2}{*}{$\begin{array}{l}\text { Maize } \\
\text { cultivar }\end{array}$} & \multirow{2}{*}{$\begin{array}{l}\text { Leaf } \\
\text { position }^{a}\end{array}$} & \multicolumn{3}{|l|}{ Treatment } \\
\hline & & $\begin{array}{l}\text { Control } \\
\text { (untreated) }\end{array}$ & $\begin{array}{l}\text { Mite } \\
\text { infested }\end{array}$ & Drought \\
\hline \multirow[t]{2}{*}{ ISO } & 8 & $88.6 \pm 4.1 \mathrm{~b}$ & $\begin{array}{c}87.0 \pm 1.0 \\
b\end{array}$ & $\begin{array}{c}50.8 \pm 4.2 \\
\mathrm{a}\end{array}$ \\
\hline & 10 & $87.0 \pm 2.7 \mathrm{~b}$ & $\begin{array}{c}85.1 \\
b\end{array}$ & $\begin{array}{l}59.7 \pm 5.1 \\
\mathrm{a}\end{array}$ \\
\hline \multirow[t]{2}{*}{ YG } & 8 & $88.8 \pm 2.8 \mathrm{c}$ & $\begin{array}{c}83.1 \pm 2.6 \\
b\end{array}$ & $\begin{array}{c}51.0 \pm 4.5 \\
\mathrm{a}\end{array}$ \\
\hline & 10 & $87.8 \pm 0.3 b$ & $\begin{array}{c}87.6 \pm 1.0 \\
b\end{array}$ & $\begin{array}{l}59.9 \pm 1.6 \\
\mathrm{a}\end{array}$ \\
\hline
\end{tabular}

Data are untransformed mean $\pm \mathrm{SD}$. Values are means of six replicates. Different letters between data in a row indicate a statistically significant difference amongst the medians at the $95 \%$ confidential level (Kruskal-Wallis test). Before analyses data were transformed (arcus sinus)

${ }^{\text {a }}$ Counting from the bottom of the stem
Water and soluble protein content

In well-watered maize plants (control), water content in leaves (estimated as RWC) did not depend on leaf position on the stem and maize cultivars (Table 1). Cessation of watering resulted in a decrease in RWC on the 6th day of soil drought. RWC of the younger leaf (10th) of both cultivars decreased less by 31-32\% than the older ones (by $43 \%$ ). The gradual development of necroses triggered by 6-day TSSM feeding on 8th leaf decreased RWC only slightly $(2-6 \%)$ regardless of maize cultivar.

The content of soluble proteins expressed per gram of DW decreased upon dehydration (Table 2) and the reduction was more pronounced in the YG (by 57 and $64 \%$ in the 8th and 10th leaf, respectively) than in the ISO (by 52 and $35 \%$ in the 8th and 10th leaf, respectively) cultivar. Feeding of TSSM decreased the level of soluble protein in mite-injured leaves of both cultivars similarly (by 31 and $26 \%$ in the 8th leaf of ISO and YG cultivar, respectively). In the non-infested 10th leaf of the ISO cultivar, the content of soluble proteins was the same as in the respective control leaf, whereas in the non-infested 10th leaf of YG cultivar the soluble protein content increased by $18 \%$.

\section{Activity of antioxidant enzymes}

Since drought resulted in a marked reduction of soluble protein level, enzymatic activities were expressed per gram of DW (Fig. 1a-f). However, the calculation of enzyme activity on an mg protein basis is also given as supplementary material (Fig. 1S A-F).

The activity of SOD in control well-hydrated leaves were higher in older than in the younger leaves of both cultivars (Fig. 1a, b). In both cultivars, the changes in the SOD activity depended on the kind of stress $\left(F_{2,12}=158.66\right.$; $p<0.0001$ for ISO; $F_{2,12}=1,519.97 ; p<0.0001$ for $\left.\mathrm{YG}\right)$ and leaf position $\left(F_{2,12}=12.71 ; p=0.0039\right.$ for ISO; $F_{2,12}=743.27 ; p<0.0001$ for YG) (Fig. 1a, b). TSSM feeding on the 8th leaf lowered substantially the total

Table 2 The soluble protein content $\left(\mathrm{mg} \times \mathrm{g}^{-1} \mathrm{DW}\right.$ ) in the 8 th and 10th leaf of maize plant subjected to soil drought (both leaves) or TSSM feeding (the 8th leaf)

\begin{tabular}{|c|c|c|c|c|}
\hline \multirow[t]{2}{*}{ Maize cultivar } & \multirow[t]{2}{*}{ Leaf position ${ }^{a}$} & \multicolumn{3}{|l|}{ Treatment } \\
\hline & & Control (untreated) & Mite infested & Drought \\
\hline \multirow[t]{2}{*}{ ISO } & 8 & $22.34 \pm 1.32 \mathrm{c}$ & $15.04 \pm 0.60 \mathrm{~b}$ & $10.35 \pm 0.18 \mathrm{a}$ \\
\hline & 10 & $17.66 \pm 0.24 \mathrm{~b}$ & $17.15 \pm 0.27 \mathrm{~b}$ & $11.52 \pm 0.40 \mathrm{a}$ \\
\hline \multirow[t]{2}{*}{ YG } & 8 & $14.41 \pm 0.14 \mathrm{c}$ & $10.60 \pm 0.49 \mathrm{~b}$ & $6.09 \pm 0.24 \mathrm{a}$ \\
\hline & 10 & $18.67 \pm 0.32 \mathrm{~b}$ & $22.27 \pm 0.42 \mathrm{c}$ & $6.71 \pm 0.17 \mathrm{a}$ \\
\hline
\end{tabular}

Data are untransformed mean \pm SD. Values are means of six replicates. Different letters between data in a row indicate a statistically significant difference amongst the medians at the $95 \%$ confidential level (Kruskal-Wallis test)

a Counting from the bottom of the stem 

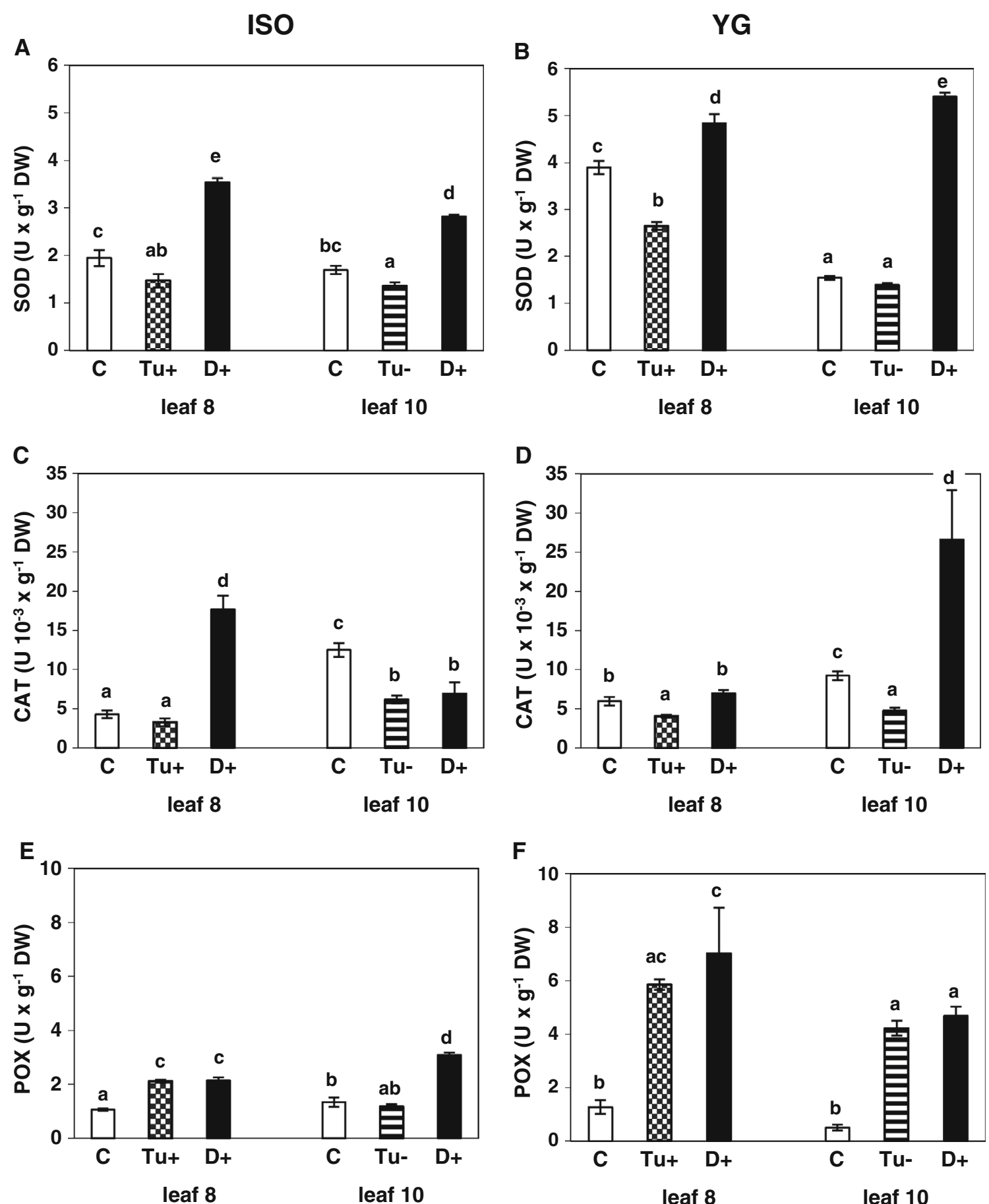

Fig. 1 The changes in the activity $\left(\mathrm{U} \times \mathrm{g}^{-1} \mathrm{DW}\right)$ of superoxide dismutase (SOD), catalase (CAT) and peroxidase (POX) in the 8th and 10th leaf of ISO (non-Bt) and YG (Bt) maize cultivars $(\mathbf{a}, \mathbf{c}, \mathbf{e}$ and b, d, f, respectively) subjected to 6-day mite feeding or soil drought. $C$ control (8th or 10th leaf from non-stressed plants), $T u+$ miteinfested 8th leaf, $D+$ drought-treated 8th or 10th leaf, $T u-$ non-

$\mathbf{F}$

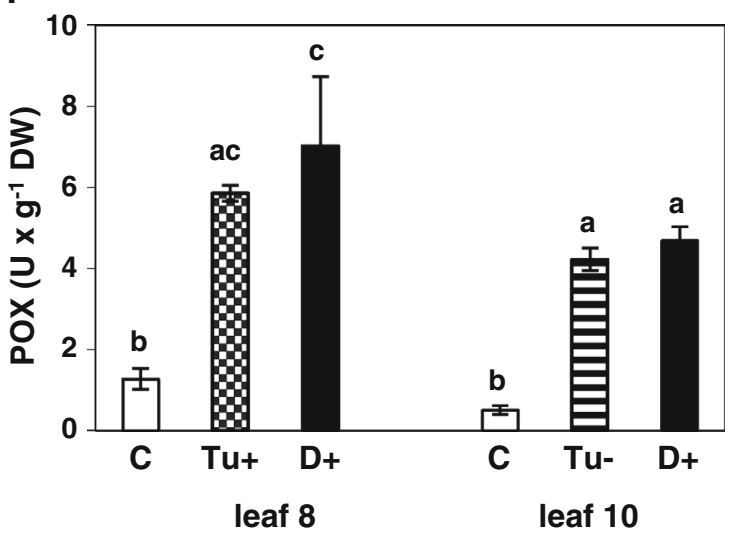

infested 10th leaf close to the mite-infested ones. 'Tu' means Tetranychus urticae. Values are means of three replicates \pm standard deviation (SD). Different letters above bars indicate a statistically significant difference at the $95 \%$ confidential level (ANOVA; HSDTukey test)

activity of SOD by 24 and $32 \%$ for ISO and YG, respectively, whereas water deficit in leaves enhanced it independently of leaf position on stem. In comparison with the control, SOD activity in the non-infested 10th leaf (spatially

separated from the mite infested) of YG and ISO plants was lowered by 11 and $20 \%$, respectively.

The changes in pattern of SOD activity in gel (Fig. 2a, b) reflected the changes in total activity of SOD (Fig. 1a, 
A

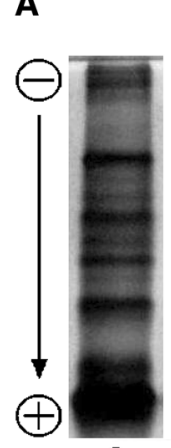

B

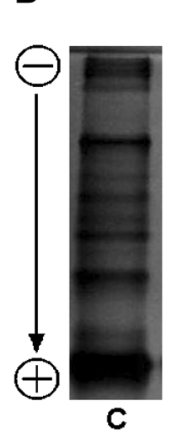

Leaf 8

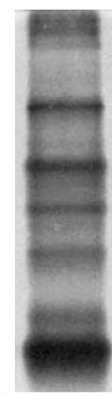

$\mathrm{Tu}+$

Leaf 8

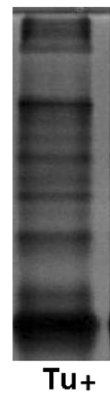

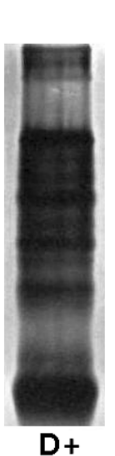

D+

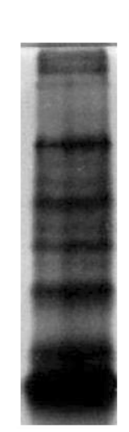

C Leaf 10
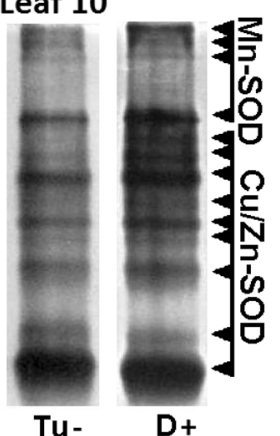

A

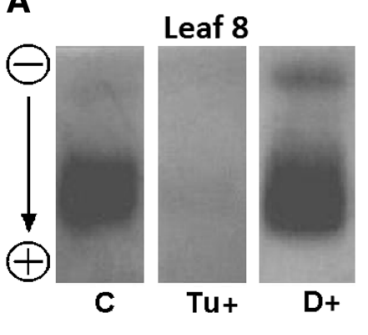

B

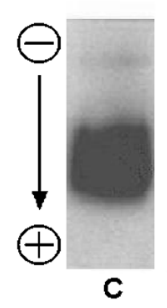

Leaf 8

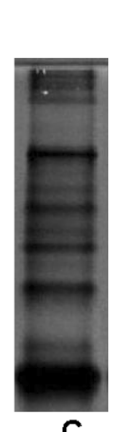

Leaf 10

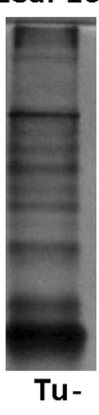

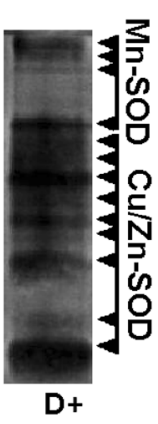

Fig. 2 The changes in the activity of superoxide dismutase (SOD) in the 8th and 10th leaf of ISO (non-Bt) (a) and YG (Bt) (b) maize cultivars subjected to 6-day mite feeding or soil drought detected by non-denaturing PAGE. $C$ control (8th or 10th leaf from non-stressed plants), $T u+$ mite-infested 8th leaf, $D+$ drought-treated 8th or 10th leaf, $T u-$ non-infested 10th leaf close to the mite-infested ones. Leaf extracts were loading at $40 \mu \mathrm{g}$ soluble protein level per lane. Representative examples of the results are presented

b). Regardless of the maize cultivar, the native PAGE assessment of SOD activities in untreated leaves of maize revealed four mitochondrial Mn-SOD bands, eight cytosolic and one chloroplastic Cu/Zn-SOD (Fig. 2a, b and Fig. 2S: Supplementary Material). Regardless of leaf age the activity of chloroplastic $\mathrm{Cu} / \mathrm{Zn}-\mathrm{SOD}$ band was the highest. Fe-SOD was undetectable as it was observed earlier (Baum and Scandalios 1981; Kernodle and Scandalios 2001; Mauro et al. 2005; Scandalios 2005). Dehydration of ISO leaves elevated SOD activity bands, whereas mite infestation decreased it. In leaves of YG cultivar, the various effects of soil drought and TSSM feeding on SOD activity pattern were not so evidently expressed: bands representing SODs of drought- and mitetreated plants were comparable in quantity but differed in intensity (Fig. 2a, b).

In both cultivars, the changes in the activity of leaf CAT upon TSSM feeding and soil water deficiency depended on the kind of stress $\left(F_{2,12}=68.38 ; p<0.0001\right.$ for ISO; $F_{2,12}=191.34 ; p<0.0001$ for $\left.\mathrm{YG}\right)$ and leaf position $\left(F_{2,12}=25.05 ; p=0.0003\right.$ for ISO; $F_{2,12}=125.85$;
Fig. 3 The changes in the activity of catalase (CAT) in the 8th and 10th leaf of ISO (non-Bt) (a) and YG (Bt) (b) maize cultivars subjected to 6-day mite feeding or soil drought detected by nondenaturing PAGE. $C$ control (8th or 10th leaf from non-stressed plants), $T u+$ mite-infested 8th leaf, $D+$ drought-treated 8th or 10th leaf, $T u-$ non-infested 10th leaf close to the mite-infested ones. Leaf extracts were loading at $40 \mu \mathrm{g}$ soluble protein level per lane. Representative examples of the results are presented

$p<0.0001$ for YG) (Fig. 1c, d). The TSSM feeding did not affect the activity of the enzyme in the ISO cultivar and resulted in a decrease of YG catalase activity (by $49 \%$ ). Water deficiency enhanced CAT activity in both 8th (by $313 \%$ for ISO and $17 \%$ for YG) and 10th (by $188 \%$ for YG) leaves with the exception of the 10th leaf of the ISO cultivar.

In all fully hydrated leaves of both maize cultivars, peroxisomal (CAT-2) and mitochondrial (CAT-3) activity bands were detectable (Fig. 3a, b) as it was observed earlier (Scandalios 1994; Prasad 1996). The activity of CAT-2 was a dominant form in 8th and 10th maize leaves and seems to be responsible for the majority of the leaf CAT activity at this stage of plant development, whereas the CAT-3 activity band was practically undetectable in control ISO maize. TSSM feeding resulted in a substantial decrease of activity of CAT-3 and CAT-2 in the 8th leaf of both cultivars, whereas in the 10th leaf the intensity of CAT-2 band was practically the same. The opposite effect was achieved in dehydrated leaves: the activity of CAT-2 highly increased, more in the transgenic YG than in the ISO, with the exception of the 10th leaf of the ISO cultivar.

The activity of guaiacol POX was comparable in the control 8th leaf of both maize cultivars (Fig. 1e, f). In both cultivars, the changes in POX activity in response to TSSM feeding and soil water deficiency depended on the kind of stress $\left(F_{2,12}=180.45 ; p<0.0001\right.$ for ISO; $F_{2,12}=$ 131.36; $p<0.0001$ for YG) (Fig. 1e, f). Feeding of TSSM 
A

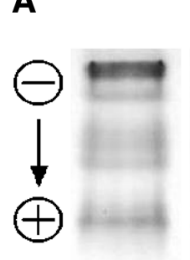

Leaf 8

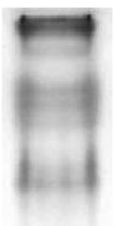

C

B

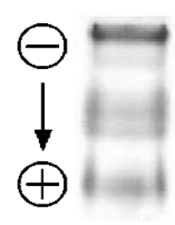

C
$\mathrm{Tu}+$

Leaf 8

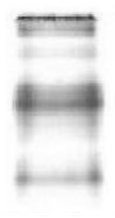

$\mathrm{Tu}+$

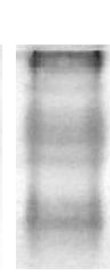

$\mathrm{D}+$

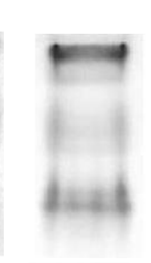

C

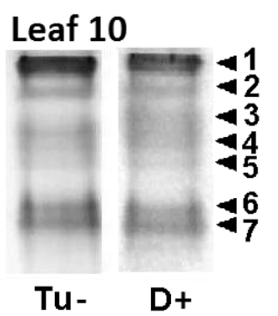

Fig. 4 The changes in the activity of peroxidase (POX) in the 8th and 10th leaf of ISO (non-Bt) (a) and YG (Bt) (b) maize cultivars subjected to 6-day mite feeding or soil drought detected by nondenaturing PAGE. $C$ control (8th or 10th leaf from non-stressed plants), $T u+$ mite-infested 8th leaf, $D+$ drought-treated 8th or 10th leaf, $T u-$ non-infested 10th leaf close to the mite-infested ones. Leaf extracts were loading at $40 \mu \mathrm{g}$ soluble protein level per lane. Representative examples of the results are presented

increased the total POX activity in the 8th leaf of the ISO and YG cultivars about 100 and $360 \%$, respectively. It is interesting to note a more than sevenfold increase of POX activity in the non-infested 10th leaf neighbouring the mite-infested ones (the 8th leaf) in the YG cultivar. Such induction was not observed in the 10th leaf of the ISO. The dehydration of leaves changed the total activity of POX either similarly (ISO, the 8th leaf) or more strongly than TSSM infestation (YG, the 8th leaf).

Using benzidine as a hydrogen donor, in control leaves of various ages of both maize cultivars, seven activity bands of POX similar in intensity were detected with dominating $\mathrm{POX}_{3-5}$ bands (close to '-' pole) in the 8th leaf and $\mathrm{POX}_{6-7}$ bands (close to ' + ' pole) in the 10th leaf (Fig. 4a, b). In both cultivars, feeding by TSSM triggered an increase in the activity of POX $_{3-5}$. In the 10th leaf (noninfested), the activity of POX in gel remained the same in YG plants or strongly increased in ISO plants. The dehydration of maize increased the activity of $\mathrm{POX}_{3-5}$ and POX $_{6-7}$ bands in the 8th leaf of both cultivars, whereas in the dehydrated 10th leaf, the activity of POX bands increased more in the ISO than in YG cultivar.

\section{Discussion}

In our study, the presence of Cry protein in insect-resistant Bt maize (YG) did not affect the leaf hydration and electrophoretic patterns of antioxidative enzymes. However, significant differences have been found between cultivars in the content of leaf soluble proteins and the specific activities of all studied enzymes in response to TSSM leaf injury and leaf dehydration.

The various levels of RWC decrease in dehydrated leaves of various positions on the stem in both cultivars of maize indicate that the effect of 6-day cessation of soil watering depends on the leaf age but not on the maize cultivar. The water deficit in maize leaves resulted in a decrease of the soluble protein content more in the transgenic YG than in the non-transgenic ISO maize. Lower protein content in leaves is probably a result of a transition of metabolism from protein synthesis to hydrolysis (Callis 1995; Ingram and Bartels 1996; Foyer and Noctor 2009) and enhanced protein degradation induced by water deficiency in soil (Wiśniewski and Zagdańska 2001; Bray 2002; Hieng et al. 2004). Variability in the content of soluble protein in transgenic crops under environmental stresses is a well-known phenomenon affecting the level of insecticidal Bt protein (reviewed by Dong and Li 2007).

In our study, increase in the activities of all investigated leaf enzymes upon soil drought has been found in both maize cultivars. Up-regulation of the activities of diverse antioxidant enzymes, including SOD, CAT and POX in response to drought (Zhang et al. 2007; Miller et al. 2010; Singh et al. 2012), low temperature (Teige et al. 2004; Prasad 1996), salinity (Borsani et al. 2005) and other abiotic stresses (Gill and Tuteja 2010; Jaspers and Kangasjärvi 2010; Suzuki et al. 2012) has been established previously. Observed here, at an early stage of soil drought, a marked increase in the activity of mainly mitochondrial Mn-SODs and cytosolic $\mathrm{Cu} / \mathrm{Zn}$-SODs may suggest that they are involved in an adjustment_of maize to water deficiency due to their crucial role in $\mathrm{O}_{2}$ scavenging and $\mathrm{H}_{2} \mathrm{O}_{2}$ formation within cells (Matters and Scandalios 1986). Such a possibility is additionally indicated by a higher activity of mitochondrial isoforms of catalase, i.e. CAT-2 and dehydration-induced CAT-3 activity band. Enhanced activity of CAT in concert with the enhanced activity of mitochondrial $\mathrm{Mn}$-SODs and cytosolic $\mathrm{Cu} / \mathrm{Zn}$-SODs may result from the increased respiratory energy production under unfavourable environmental conditions that was previously observed both in acclimated wheat leaves and in leaves stressed by soil drought (Zagdańska 1995).

In both cultivars, TSSM feeding on the 8th leaf for 6 days decreased the total activity of SOD and CAT, whereas it increased the guaiacol POX activity. However, there are equivocal results regarding antioxidant responses in different plant-mite pest interactions (Hildebrand et al. 1986; Bronner et al. 1991; Stout et al. 1994, 1996; Tomczyk 2001; Kielkiewicz 2002; Kielkiewicz et al. 2008; Masserti et al. 2011). Found here, a lower activity of cytosolic $\mathrm{Cu} / \mathrm{Zn}$-SODs and unchanged activity of 
chloroplastic $\mathrm{Cu} / \mathrm{Zn}$-SOD and mitochondrial Mn-SOD isoforms within cells of mite-infested leaves suggest that the accumulation of $\mathrm{H}_{2} \mathrm{O}_{2}$ within cell compartments of these leaves seems to occur but not necessarily remains in place. This conclusion is supported by the findings that the intra-cellular ROS generation is rather transient under initial periods of various kinds of stresses (Fossdal et al. 2007; Cardenas et al. 2008; Kuśnierczyk et al. 2008; Masserti et al. 2011).

Catalase-2 activity band in the mite-infested 8th leaf of both maize cultivars was down-regulated as it has been observed in citrus leaves at the initial period of TSSM infestation (Masserti et al. 2011). Our results are consistent with the suggestion that in plants subjected to biotic stress the diminished activity of CAT and APX results in localized increases of ROS and mediates in programmed cell death (Dorey et al. 1998; Mittler et al. 1998, 1999).

The increased activity of guaiacol POX in mite-infested and drought-treated maize leaves of both cultivars confirms the earlier observation that POX activity increase is a rather common response to suboptimal growth of temperature in maize seedlings (Prasad 1996) as well as to piercing/ sucking by hemipteran, biting by dipteran or chewing by lepidopteran insect pests in many mono- and dicots (Stout et al. 1994, 1996; Argandoña et al. 2001; Maffei et al. 2006; Kuśnierczyk et al. 2008; Wei et al. 2009; Zhou et al. 2010; He et al. 2011). However, the present results showed that the response of benzidine POX activities to both, TSSM and drought stresses, was different since the activity of $\mathrm{POX}_{3-5}$ bands increased more in the 8th mite-injured leaf than in the 8th drought-treated leaf. Moreover, in dehydrated 8th leaf the increased activity of $\mathrm{POX}_{6-7}$ bands took place. This may indicate a tight regulation of the enzyme to adjust to different kinds of stress.

Our results provide evidence that protein biosynthesis took place systemically in the non-infested leaf of miteinfested Bt maize as it has previously been shown for other host plant-herbivore interactions (Stout et al. 1996; Arimura et al. 2000; Divol et al. 2005; Smith and Boyko 2007). Since it is clear that leaf insecticidal $\mathrm{Bt}$ protein contributes to the total soluble protein (Chen et al. 2005), it seems possible that the systemic increase of soluble protein content may have implications for the level of the insecticidal toxin in $\mathrm{Bt}$ maize partially infested by TSSM. This is supported by the evidence of significant positive correlation between $\mathrm{Bt}$ toxin and soluble protein content in transgenic $\mathrm{Bt}$ cotton treated by extreme temperatures for a short time (Chen et al. 2013), waterlogging and a combination of salinity and waterlogging (Luo et al. 2008). It should also be underlined that the non-infested leaf of mite-infested transgenic maize developed the systemic response by considerably increasing the activities of POX (specific and "in gel") and CATs. Although the reason of this phenomenon is not yet clear, one can suppose that POX may be involved in the process of transferring oxidation into redox signals controlling defencerelated responses as it has previously been reported (Kawano 2003) or high responsiveness of this enzyme may locally detoxify overabundance of $\mathrm{H}_{2} \mathrm{O}_{2}$ by cell wall lignification and chlorotic lesion formation.

Data in literature, concerning traits mediating in the resistance of maize to insects, (reviewed by Meihls et al. 2014) suggest however that the content of native or arthropod-induced compounds such as benzoxazinoids (DIMBOA [2,4-dihydroxy-7-methoxy-1,4-benzoxazin-3one], MBOA, HDMBOA), protease inhibitors, lignin or silica might also be engaged in modulating the response of Bt and non-Bt maize to TSSM. For example, lower content of DIMBOA and phenolics in Bt maize compared with non-Bt maize was linked to a greater susceptibility of $\mathrm{Bt}$ maize to non-target insect pests (Nie et al. 2005). Recently, the decrease of the constitutive level of gossypol and tannin in Bt cotton transformed with CrylAc or CrylAc/CpTi genes was correlated to the increased performance of the non-target arthropod-the cotton spider mite (Ma et al. 2014). In the case of Bt maize leaf, although the abundance of lignin was found to be much higher than in non-Bt leaf (Saxena and Stotzky 2001), mite reproduction potential on the Bt maize leaf did not differ from that of its non-Bt counterparts (Dutton et al. 2002).

In conclusion, the kind of stress (soil drought vs. mite feeding) rather than just the presence of the Cry protein determines how the Bt maize counteracts the results of unique stress conditions. An increased activity of SOD, CAT and POX in dehydrated, fully expanded leaves of maize plants $\left(\mathrm{V}_{12}\right)$ suggests a limitation of ROS production and/or accumulation. In contrast, the decreased activity of cytosolic isoforms of SOD together with a still steady-state level of chloroplastic and mitochondrial isoforms of SOD in miteinjured leaves indicates the restricted generation of $\mathrm{H}_{2} \mathrm{O}_{2}$ in the cytosol and a slightly changed conversion of $\mathrm{O}_{2}$ to $\mathrm{H}_{2} \mathrm{O}_{2}$ within chloroplasts and mitochondria. These findings together with a lowered activity of CAT-2 and a marked increase of POX suggest that Bt-maize POX might contribute to the management of short-term mite infestation. The engagement of other ROS-scavenging enzymes in local and systemic maize responses to both stresses acting separately and in combination is currently under investigation.

Author contribution MS carried out the experiment and biochemical analyses, performed data analyses and prepared all tables and figures. MK and BZ equally contributed to the experimental setup and manuscript preparation.

Acknowledgments Authors thank to Monsanto for providing the maize seeds. This work was supported by a Grant No. N N310 038338 obtained from The Ministry of Science and Higher Education (Poland). 
Conflict of interest All authors declare no knowledge of conflict of interest regarding this research.

Open Access This article is distributed under the terms of the Creative Commons Attribution License which permits any use, distribution, and reproduction in any medium, provided the original author(s) and the source are credited.

\section{References}

Ahmed AG, Mekki BB (2005) Yield and yield components of two maize hybrids as influenced by water deficit during different growth stages. Egypt J Appl Sci 20:64-79

Argandoña VH, Chaman M, Cardemil L, Muñoz O, Zuñiga GE, Corcuera LJ (2001) Ethylene production and peroxidase activity in aphid-infested barley. J Chem Ecol 27:53-68

Arimura G, Tashiro K, Kuhara S, Nishioka T, Ozawa R, Takabayashi $\mathrm{J}$ (2000) Gene responses in bean leaves induced by herbivory and by herbivore-induced volatiles. Biochem Biophys Res Commun 277:305-310

Atkinson NJ, Urwin PE (2012) The interaction of plant biotic and abiotic stresses: from genes to the field. J Exp Bot 63:354-3523

Barrs HD (1968) Determination of water deficits in plant tissues. In: Kozlowski TT (ed) Water deficits and plant growth, vol I., Development, control and measurementAcademic Press, New York, pp 235-368

Bartoli CG, Casalongue CA, Simontacchi M, Marquez-Garcia B, Foyer CH (2013) Interaction between hormone and redox signalling pathways in the control of growth and cross tolerance to stress. Environ Exp Bot 94:73-88

Baum JA, Scandalios JG (1981) Isolation and characterization of the cytosolic and mitochondrial superoxide dismutases of maize. Arch Biochem Biophys 206:249-264

Beauchamp C, Fridovich I (1971) Superoxide dismutase: improved assays and an assay applicable to acrylamide gels. Anal Biochem 44:276-287

Borsani O, Zhu J, Verslues PE, Sunkar R, Zhu JK (2005) Endogenous siRNAs derived from a pair of natural cis-antisense transcripts regulate salt tolerance in Arabidopsis. Cell 123:279-1291

Bradford MM (1976) A rapid and sensitive method for the quantification of microgram quantities of protein utilizing the principle of protein dye-binding. Anal Biochem 72:248-254

Bray EA (2002) Classification of genes differentially expressed during water deficit stress in Arabidopsis thaliana: an analysis using microarray and differential expression data. Ann Bot 89:803-811

Bronner R, Westphal E, Dreger F (1991) Enhanced peroxidase activity associated with the hypersensitive response of Solanum dulcamara to the gall mite Aceria cladophthirus (Acari: Eriophyoidea). Can J Bot 69:2192-2196

Callis J (1995) Regulation of protein degradation. Plant Cell 7:845-857

Cardenas L, Martinez A, Sanchez F, Quinto C (2008) Fast, transient and specific intracellular ROS changes in living root hair cells responding to Nod factors (NFs). Plant J 56:802-813

Chen DH, Ye GY, Yang CQ, Chen Y, Wu YK (2005) The effect of high temperature on the insecticidal properties of Bt cotton. Environ Exp Bot 53:333-342

Chen Y, Wen Y, Chen Y, Zhang X, Wang Y, Chen D (2013) The recovery of Bt toxin content after temperature stress termination in transgenic cotton. Span J Agric Res 11(2):438-446

De Angelis JD, Berry RE, Krantz GW (1983) Evidence for spider mite (Acari: Tetranychidae) injury-induced leaf water deficits and osmotic adjustment in peppermint. Environ Entomol 12:336-339

Divol F, Vilaine F, Thibivilliers S, Amselem J, Palauqui JC, Kusiak C, Dinant S (2005) Systemic response to aphid infestation by Myzus persicae in the phloem of Apium graveolens. Plant Mol Biol 57:517-540

Dong HZ, Li WJ (2007) Variability of endotoxin expression in $\mathrm{Bt}$ transgenic cotton. J Agron Crop Sci 193:21-29

Dorey S, Baillieul F, Saindrenan P, Fritig B, Kauffmann S (1998) Tobacco class I and II catalases are differentially expressed during elicitor-induced hypersensitive cell death and localized acquired resistance. Mol Plant Microbe Interact 11:1102-1109

Dutton A, Klein H, Romeis J, Bigler F (2002) Uptake of Bt-toxin by herbivores feeding on transgenic maize and consequences for the predator Chrysoperla carnea. Ecol Entomol 27:441-447

Fossdal CG, Nagy NE, Johnsen O, Dalen LS (2007) Local and systemic stress responses in Norway spruce: similarities in gene expression between compatible pathogen interaction and drought stress. Physiol Mol Plant Pathol 70:161-173

Foyer CH, Noctor G (2009) Redox regulation in photosynthetic organisms: signaling, acclimation, and practical implications. Antioxid Redox Signal 11:861-905

Foyer CH, Noctor G (2011) Ascorbate and glutathione: the heart of the redox hub. Plant Physiol 155:2-18

Fridovich I (1986) Superoxide dismutase. Adv Enzymol Relat Areas Mol Biol 58:61-97

Gill SS, Tuteja N (2010) Reactive oxygen species and antioxidant machinery in abiotic stress tolerance in crop plants. Plant Physiol Biochem 48:909-930

He J, Chen F, Chen S, Lv G, Denga Y, Fang W, Liu Z, Guan Z, He C (2011) Chrysanthemum leaf epidermal surface morphology and antioxidant and defense enzyme activity in response to aphid infestation. J Plant Physiol 168:687-693

Hieng B, Ugrinovič K, Šuštar-Vozlič J, Kidrič M (2004) Different classes of proteases are involved in the response to drought of Phaseolus vulgaris L. cultivars differing in sensitivity. J Plant Physiol 161:519-539

Hildebrand DF, Rodriguez JG, Brown GC, Luu KT, Volden CS (1986) Peroxidative responses of leaves in two soybean genotypes injured by two-spotted spider mites (Acari: Tetranychidae). J Econ Entomol 79:1459-1465

Huang W, Jia ZK, Han QF (2007) Effects of herbivore stress by Aphis medicaginis Koch on the malondialdehyde contents and the activities of protective enzymes in different alfaalfa varieties. Acta Ecol Sinica 27:2177-2183

Ingram J, Bartels D (1996) The molecular basis of dehydration tolerance in plants. Annu Rev Plant Physiol Plant Mol Biol 47:377-403

Jaspers P, Kangasjärvi J (2010) Reactive oxygen species in abiotic stress signaling. Physiol Plant 138:405-413

Kawano T (2003) Roles of the reactive oxygen species-generating peroxidase reactions in plant defense and growth induction. Plant Cell Rep 21:829-837

Kernodle SP, Scandalios JG (2001) Structural organization, regulation, and expression of the chloroplastic superoxide dismutase Sodl gene in maize. Arch Biochem Biophys 391:137-147

Kielkiewicz M (1999) Ultrastructural cell modification in tomato (Lycopersicon esculentum) leaf tissue in response to the carmine spider mite (Tetranychus cinnabarinus) feeding. In: Bruin J, Van der Geest LPS, Sabelis MW (eds) Ecology and evolution of the Acari. Kluver Academic Publishers, Dordrecht, pp 603-615

Kielkiewicz M (2002) Influence of carmine spider mite, Tetranychus cinnabarinus Boisd. (Acarina: Tetranychidae) feeding on ethylene production and the activity of oxidative enzymes in damaged tomato plants. In: Bernini F, Nannelli R, Nuzzaci G, de Lillo E 
(eds) Acari: phylogeny and evolution, adaptations in mites and ticks. Kluwer Academic Publishers, Dordrecht, pp 389-392

Kielkiewicz M, Miazek A, Szwacka M (2008) Local and systemic responses induced by Tetranychus urticae (Acari: Prostigmata: Tetranychidae) feeding in cucumber plants transformed with thaumatin II gene. In: Bertrand M, Reiter S, McCoy KD, Migeon A, Navajas M, Tixier MS, Vial L (eds) Integrative acorology. Creative Commons-BY-NC-ND, pp 472-477. http://creativecom mons.org/licenses/by-nc-nd/2.0/fr

Kuśnierczyk A, Winge P, Jørstad TS, Troczyńska J, Rossiter JT, Bones AM (2008) Towards global understanding of plant defence against aphids-timing and dynamics of early Arabidopsis defence responses to cabbage aphid (Brevicoryne brassicae) attack. Plant Cell Environ 31:1097-1115

Kwak JM, Nguyen V, Schroeder I (2006) The role of reactive oxygen species in hormonal responses. Plant Physiol 141:323-329

Laemmli UK (1970) Cleavage of structural protein during the assembly of the head of bacteriophageT4. Nature 227:680-685

Luo Z, Dong H, Li W, Ming Z, Zhu Y (2008) Individual and combined effects of salinity and waterlogging on Cry $1 \mathrm{Ac}$ expression and insecticidal efficacy of Bt cotton. Crop Prot 27:1485-1490

Ma H, Zhao M, Wang H, Wang Z, Wang Q, Dong H (2014) Comparative incidence of cotton spider mites on transgenic $\mathrm{Bt}$ versus conventional cotton in relation to contents of secondary metabolites. Arthropod Plant Interact 8:1-7

Maffei ME, Mithofer A, Arimura GI, Uchtenhagen H, Bossi S, Bertea CM, Cucuzza LS, Novero M, Volpe V, Quadro S, Boland W (2006) Effects of feeding Spodoptera littoralis on Lima bean leaves. III. Membrane depolarization and involvement of hydrogen peroxide. Plant Physiol 140:1022-1035

Masserti BE, Del Carrtore R, Della Croce CM, Podda A, Migheli Q, Froelicher Y, Luro F, Morillon R, Ollitrarault P, Talon M, Rossignol M (2011) Comparative analysis of proteome changes induced by the two spotted spider mite Tatranychus urticae and methyl jasmonate in citrus leaves. J Plant Physiol 168:392-402

Matters GL, Scandalios JG (1986) Effect of the free radicalgenerating herbicide paraquat on the expression of the superoxide dismutase $(\mathrm{Sod})$ genes in maize. Biochim Biophys Acta 882:29-38

Mauro S, Van Eycken F, Challou N, Lucas P, L'Oiseau M (2005) Characterization of new maize chloroplastic copper/zinc superoxide dismutase isoforms by high resolution native two-dimensional polyacrylamide gel electrophoresis. Identification of chilling responsive chloroplastic superoxide dismutase isoforms. Physiol Plant 124:323-335

Meihls LN, Kaur H, Jander G (2014) Natural variation in maize defense against insect herbivores. Cold Spring Harb Symp Quant Biol 201277:269-283

Meissle M, Mouron P, Musa T et al (2010) Pests, pesticide use and alternative options in European maize production: current status and future prospects. J App Entomol 134:357-375

Miller G, Suzuki N, Ciftci-Yilmaz S, Mittler R (2010) Reactive oxygen species homeostasis and signaling during drought and salinity stresses. Plant Cell Environ 33:453-467

Mittler R, Feng X, Cohen M (1998) Post-transcriptional suppression of cytosolic ascorbate peroxidase expression during pathogeninduced programmed cell death in tobacco. Plant Cell 10:3461-3473

Mittler R, Herr EH, Orvar BL, van Camp W, Willekens H, Inze D, Ellis B (1999) Transgenic tobacco plants with reduced capability to detoxify reactive oxygen intermediates are hypersensitive to pathogen infection. Proc Nat Acad Sci USA 96:14165-14170
Neill S, Desikan R, Clarke A, Hurst RD, Hancock JT (2002) Hydrogen peroxide and nitric oxide as signalling molecules in plants. J Exp Bot 53:1237-1247

Nie CR, Luo SM, Lin CX, Zeng RS, Huang JH et al (2005) Status of DIMBOA and phenolic acids in transgenic Bt corn. Aust J Agric Res 56:833-837

Patykowski J, Urbanek H, Kaczorowska T (1988) Peroxidase activity in leaves of wheat cultivars differing in resistance to Erysiphe graminis DC. J Phytopathol 122:126-134

Prasad TK (1996) Mechanisms of chilling-induced oxidative stress injury and tolerance in developing maize seedlings, changes in antioxidant system, oxidation of proteins and lipids, and protease activities. Plant J 10:1017-1026

Rani PU, Jyothsna Y (2010) Biochemical and enzymatic changes in rice plants as a mechanism of defense. Acta Physiol Plant 32:695-701

Rao MV, Paliyath G, Ormrod DP (1996) Ultraviolet-B radiation and ozone-induced biochemical changes in the antioxidant enzymes of Arabidopsis thaliana. Plant Physiol 110:125-136

Salin ML, Lyon DS (1982) Iron containing superoxide dismutases in eucaryotes: localization in chloroplasts from water lily, Nuphar luteum. In: Cohen G, Greenwald RA (eds) Superoxide dismutase, superoxide and oxy radicals. Biochemical aspects. Elsevier Biomedical Press, Amsterdam, pp 344-347

Saxena D, Stotzky G (2001) Bt corn has a higher lignin content than non-Bt corn. Am J Bot 88:1704-1706

Scandalios JG (1994) Molecular biology of superoxide dismutase. In: Alscher RG, Welburn AR (eds) Plant responses to the gaseous environment: molecular, metabolic and physiological aspects. Chapman \& Hall, London, pp 147-164

Scandalios JG (2005) Oxidative stress: molecular perception and transduction of signals triggering antioxidant gene defenses. Braz J Med Biol Res 38:995-1014

Singh S, Gupta K, Kaur N (2012) Differential responses of antioxidative defence system to long-term field drought in wheat (Triticum aestivum L.). genotypes differing in drought tolerance. J Agron Crop Sci 198:185-195

Ślesak I, Libik M, Karpinska B, Karpinski S, Miszalski Z (2007) The role of hydrogen peroxide in regulation of plant metabolism and cellular signaling in response to environmental stresses. Acta Biochim Pol 54:39-50

Smith CM, Boyko EV (2007) The molecular bases of plant resistance and defense responses to aphid feeding: current status. Entomol Exp App 122:1-16

Stout MJ, Workman JS, Duffey SS (1994) Differential induction of tomato foliar proteins by arthropod herbivores. J Chem Ecol 20:2575-2594

Stout MJ, Workman KV, Workman JS, Duffey SS (1996) Temporal and ontogenetic aspects of protein induction in foliage of the tomato Lycopersicon esculentum. Biochem Syst Ecol 24:611-625

Suzuki N, Koussevitzky S, Mittler R, Miller G (2012) ROS and redox signalling in the response of plants to abiotic stress. Plant Cell Environ 35:259-270

Teige M, Scheikl E, Eulgem T, Dóczi R, Ichimura K, Shinozaki K, Dangl JL, Hirt H (2004) The MKK2 pathway mediates cold and salt stress signaling in Arabidopsis. Mol Cell 15:141-152

Tomczyk A (2001) Physiological and biochemical responses of plants to spider mite feeding. In: Halliday RB, Walter DE, Proctor HC, Norton RA, Colloff MJ (eds) Acarology X. CSIRO Publishing, Melbourne, pp 306-313

Torres MA (2010) ROS in biotic interactions. Physiol Plant 138:414-429

Wei Z, Hu W, Lin Q, Cheng X, Tong M, Zhu L, Chen R, He G (2009) Understanding rice plant resistance to the brown planthopper 
(Nilaparvata lugens): a proteomic approach. Proteomics 9:2798-2808

Wiśniewski K, Zagdańska B (2001) Genotype-dependent proteolytic response of spring wheat to water deficiency. J Exp Bot 52:1455-1463

Zagdańska B (1995) Respiratory energy demand for protein turnover and ion transport in wheat leaves upon water deficit. Physiol Plant 95:428-436

Zhang LX, Zhang SX, Liang ZS (2007) Nitrogen rates and water stress effect on production, lipid peroxidation and antioxidative enzyme activities in two maize (Zea mays L.) genotypes. J Agron Crop Sci 193:387-397

Zhou J, Zhou J Jr, Wu B, Qin P, Qi A (2010) Physiological factors for tolerance of Kostelezkya virginica (L.) Presl to one-instar bollworms of Helicoverpa armigera (Hübner). Acta Physiol Plant 32:519-529 